\title{
Impact of Agricultural Land Use on Nitrate Levels in Lake Manatee, Florida ${ }^{1}$
}

\author{
C.D. Stanley, R.A. Clarke, B.L. McNeal, and B.W. Macleod²
}

Nutrient enrichment of surface water bodies is often attributed to nonpoint source pollution from agricultural production areas where applied fertilizer has been leached from the point of application. Where this enrichment results in eutrophication of the water body, environmental and/or economic burdens are placed on society to live with or rectify the situation. The Lake Manatee watershed is located in the northeast sector of Manatee County, Florida. Lake Manatee Dam was constructed in 1967, and is located $39 \mathrm{~km}$ (24 mi) upstream from the entry point of the Manatee River into Tampa Bay. The area of the watershed is 33,846 ha $(83,635 \mathrm{ac})$, with its 729-ha (1800-ac) reservoir serving as the principal potable water source for over 265,000 people in Manatee and Sarasota counties. The reservoir has a relatively shallow depth, averaging $3.9 \mathrm{~m}(12.8 \mathrm{ft})$, and is well mixed with little or no stratification throughout the year (Rampenthal and Ferraro 1987). Lake Manatee is considered $\mathrm{N}$-limited and not P-limited, due to phosphatic deposits in the upper reaches of the watershed (Gee and Jensen 1984), where phosphate mining is a commercial enterprise. Since the reservoir is being used as a drinking water source, it must meet the stringent State of Florida surface water quality criteria for Class I waters; therefore, any deterioration of water quality becomes a concern.

Citrus and vegetable production in the Lake Manatee watershed may promote eutrophication of the reservoir (McNeal, et al. 1995). The fertilizer application rate for citrus and vegetable crops often exceeds rates recommended by the University of Florida because of the relatively low cost of fertilizer compared with other production costs of these high-value crops. Producers rationalize the cost of additional fertilizer as being necessary because substantial leaching can occur on these sandy soils with frequent heavy rainfall events. The relative contributions of agriculture, mining, and urban activities to nutrient loading are of primary concern to local citizens.

Using historical lake water quality data and watershed land use data, the primary objective of this study was to assess whether or not a relationship existed between agricultural activities in the watershed and nutrient loading of the reservoir and algal productivity associated with economically

1. This is document SL 209, a publication of the Soil and Water Science Department, Florida Cooperative Extension Service, IFAS, University of Florida. Published September 2003. Please visit the EDIS Website at http://edis.ifas.ufl.edu.

2. C.D. Stanley, professor, Soil and Water Science Department, Gulf Coast Research and Education Center--Dover, FL; Florida Cooperative Extension Service, IFAS, University of Florida, Gainesville, FL; R.A. Clark, environmental scientist, CH2M-Hill Associates, Gainesville, FL; B.L. McNeal, professor emeritus, Soil and Water Science Department, University of Florida, Gainesville, FL; and B.W. MacLeod, water quality supervisor, Manatee County Pubic Works Department, Bradenton, FL.

The Institute of Food and Agricultural Sciences is an equal opportunity/affirmative action employer authorized to provide research, educational information and other services only to individuals and institutions that function without regard to race, color, sex, age, handicap, or national origin. For information on obtaining other extension publications, contact your county Cooperative Extension Service office. Florida Cooperative Extension Service/Institute of Food and Agricultural Sciences/University of Florida/Christine Taylor Waddill, Dean. 
important blooms. Successful results would provide information that would benefit future land use decisions in the watershed.

\section{Materials and Methods}

Monthly water quality data for Lake Manatee have been collected since 1983 from sampling stations located at eight strategic locations in the lake. Samples are normally collected in the mid morning to early afternoon using a vertical profile Niskin sampler. Water samples are taken from the surface, middle, and bottom of the water column, mixed on-site, and placed in cold storage until the analyses can be performed. While numerous water quality parameters have been measured, those that were initially evaluated for the purposes of this study included total Kjeldahl nitrogen (TKN), ammonia, and nitrate and nitrite concentrations collected from 1983 to 1993. Since off-site $\mathrm{NO}_{3}-\mathrm{N}$ movement into Lake Manatee was of primary concern, this report will concentrate on that parameter exclusively.

Row cropped vegetable and citrus production were considered the primary intensive agricultural activities in the watershed. Vegetables are commonly grown on raised beds covered with plastic mulch. The mulch serves many functions, including facilitation of fumigation of the soil, disease and weed control, and protection of applied fertilizer from leaching during excessive rainfall events. Vegetables are either subirrigated (water moves into the bed from a managed shallow water table by capillary movement) or microirrigated (water moves through drip tubes placed on or within each bed). Since producers often apply fertilizer in amounts well above what is recommended, the potential for losses exists, especially when the plastic is removed from vegetable beds at the end of the growing season. Because vegetables are grown on soils with naturally high water table levels, there is also significant potential for denitrification of the applied fertilizer.

Citrus groves are primarily irrigated with microsprinklers and broadcast fertilized or, in some cases, fertilized by injection of liquid fertilizer into the irrigation water. Groves in this area are commonly grown on soils with deeper water tables, but are increasingly being grown on high water table soils. The broadcast fertilizer is vulnerable to leaching during most rainfall events.

To evaluate the impact of land use on nutrient enrichment of the reservoir, sub-basins were delineated with the Lake Manatee watershed corresponding to primary influence on the water quality near locations of the various water monitoring stations. Care was taken to match the proper sub-basin with the historical land use data and to determine the relationship of each sub-basin to the changing $\mathrm{NO}_{3}-\mathrm{N}$ concentrations at the most affected sampling station.

Figure 1 contains a diagram of the watershed divided into sub-basins. Water sampling stations were located within the lake to collect samples near natural drainage flow into the lake. The small streams were linked to sub-basins within the watershed and corresponding historical land use was used to determine what agricultural cropping systems may have affected the quality of the water coming that stream. Station one (S1), located next to Lake Manatee Dam, reflected land use patterns for the entire watershed since all inflows into the lake are consider combined at that point. Amounts of row crop and citrus production area remained relatively constant for the watershed during the 1980s. Station two (S2) was located in an area of the reservoir that was affected by a sub-basin with no agricultural activity throughout the course of the study. Station three (S3), located in the middle of the reservoir, reflected a land use pattern similar to that of S1. Station four (S4) was located near a sub-basin of predominantly citrus production that extended to the edges of the reservoir. Station five (S5), located in the eastern portion of the reservoir, was affected by equal areas of citrus and row crops, with much of the citrus, again, growing to the edge of the reservoir. Station six (S6), located near the south bank of the reservoir, reflected a gradual transition from citrus to row crops over the period of the study. An area containing row crops affected station seven (S7), also near the south bank. While both citrus and row crops affected station eight (S8), the furthest sampling station upstream from the dam, in particular, row cropping in the upper reaches of the watershed increased somewhat during the 1980s. 


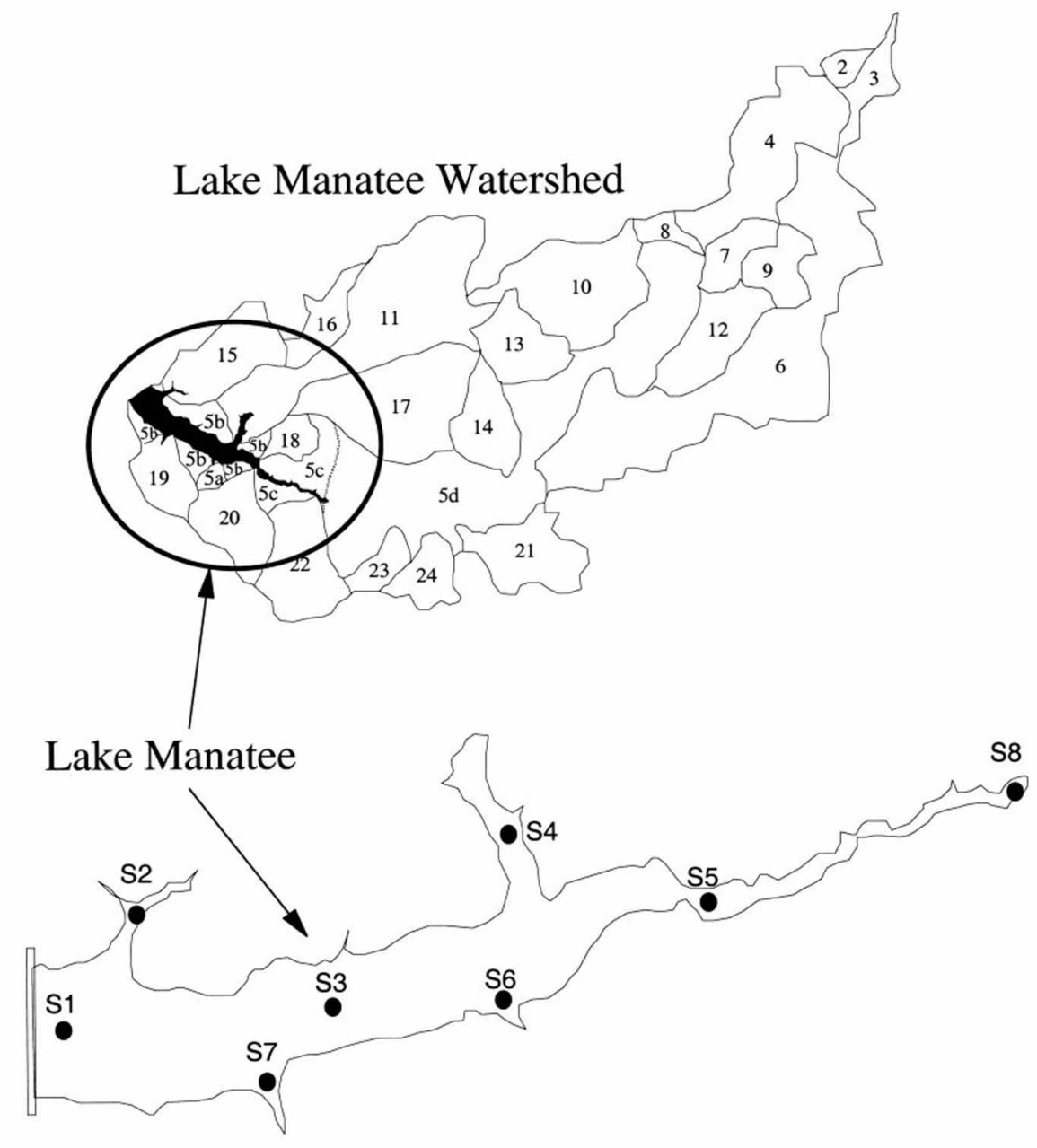

Figure 1. Diagram showing Lake Manatee, sampling station locations, and surrounding watershed (with sub-basins). Sampling stations assumed to be influenced by sub-basins as follows: S1 (all sub-basins); S2 (sub-basin 15); S3 (all sub-basins except 15, 19, and 5b); S4 (sub-basins 11, 16, and 17); S5 (sub-basins 23, 24, 31, 6, 9, 2, 3, 4, 12, 14, 8, 7, 10, 13, 5d, 20, and 22); S6 (sub-basin 5a); S7 (sub-basin 19); and S8 (sub-basins 23, 24, 21, 6, 9, 2, 3, 4, 12, 14, 8, 7, 10, 13, and $5 d)$.

Land use trends for the 10-year study period (1983 to 1993) were determined by using specific citrus and vegetable production area data for the years 1983, 1987, and 1990. Citrus and vegetable production area changes were determined using data collected by the USDA National Resources Conservation Service (NRCS) and information from the Southwest Florida Water Management District. The locations and areas of production zones corresponding to each sampling station are shown in Table 1.

Data were analyzed using trend analysis techniques (including least squares linear regression and Spearman's correlation method) to assess the correlation of $\mathrm{NO}_{3}-\mathrm{N}$ changes with land use changes over time. Because the nature of agricultural activity in the watershed involved seasonal management practices (such as fertilization applications), data were analyzed using a "deseasonalization" process to remove natural $\mathrm{NO}_{3}-\mathrm{N}$ variability, leaving primarily man-induced inputs to be considered. To quantify the amount of $\mathrm{NO}_{3}-\mathrm{N}$ attributable to agricultural activities, the $\mathrm{NO}_{3}-\mathrm{N}$ concentration data was normalized for each sampling station by calculating the average monthly $\mathrm{NO}_{3}-\mathrm{N}$ concentration for the entire study period and subtracting that value from the concentration 
measured at that site. This technique removed much of the natural variability in $\mathrm{NO}_{3}-\mathrm{N}$ and thus provided residual values reflecting $\mathrm{NO}_{3}-\mathrm{N}$ or other inputs that would cause the concentrations to deviate from the monthly norms. This technique also allowed data from each station to be viewed using the same scale, thus facilitating comparisons among different segments of the watershed.

\section{Results and Discussion}

Nitrate-nitrogen seasonal trends. Nitrate- $\mathrm{N}$ was used in this study as the primary indicator of possible agricultural inputs from runoff and/or groundwater seepage. There can be a problem with this approach, however, because $\mathrm{NO}_{3}-\mathrm{N}$ 's "natural" seasonal cycles can hide or mask changes due to human activities. Natural sources of $\mathrm{NO}_{3}-\mathrm{N}$ include decomposition of plant and animal debris, movement through natural land drainage, and aquatic plant growth and decay. Also, N-deposition from rainfall can be another source of added $\mathrm{N}$. Natural $\mathrm{N}$-sinks include those associated with the growth of algae and aquatic weeds, which is always greatest during the warmest times of the year, and the annual flushing of the reservoir through simple dilution during the summer rainy season. The annual cycle of $\mathrm{NO}_{3}-\mathrm{N}$ concentrations measured in this study shows a consistent seasonal pattern, with a general decrease during the summer months and an increase during the winter months (Figure 2). The period of decrease can be explained as a combination of dilution from rainfall and $\mathrm{NO}_{3}-\mathrm{N}$ utilization by algae and aquatic weeds. Average monthly precipitation data for the study period are also shown in Figure 2. Data from most stations followed similar $\mathrm{NO}_{3}-\mathrm{N}$ cycles except for S4, which had substantially higher concentrations throughout most of the study period.

\section{Deseasonalized $\mathrm{NO}_{3}-\mathrm{N}$ trends. The} deseasonalized data were used to determine the strength of the relationship between land use and $\mathrm{NO}_{3}-\mathrm{N}$ concentrations at each sampling station. For the purposes of illustration, a period from January 1989 to December 1992 was chosen to evaluate this relationship for sampling stations at which $\mathrm{NO}_{3}-\mathrm{N}$ concentrations were compared to key field practices (fertilization applications and removal of plastic mulch) in corresponding sub-basins.
Deseasonalized $\mathrm{NO}_{3}-\mathrm{N}$ values for data from $\mathrm{S} 4$ and $\mathrm{S} 5$, dominated by neighboring citrus sites, are shown in Figure 3. Citrus is commonly fertilized in February, May, and October (indicated by downward-oriented arrows) with broadcast applications. The $\mathrm{NO}_{3}-\mathrm{N}$ peaks did not follow a consistent pattern with respect to generalized fertilizer application dates, though some peaks did seem to occur consistently near the typical February and May fertilization dates. Several peaks may be attributed instead to runoff and/or seepage due to increased rainfall. Monthly rainfall measured at Lake Manatee for 1989 to 1992 is shown in Table 2. The peaks occurring in June 1989 and February 1992 did take place during months with above-average rainfall ( $30.5 \mathrm{~cm}$ and $20 \mathrm{~cm}$, respectively). However, other months displayed above-average monthly rainfall totals as well, without exhibiting significant $\mathrm{NO}_{3}-\mathrm{N}$ peaks. Overall, data from these sampling stations showed considerable variation in their $\mathrm{NO}_{3}-\mathrm{N}$ values.

Deseasonalized $\mathrm{NO}_{3}-\mathrm{N}$ data for $\mathrm{S} 2$, which reflected no agricultural activity during the study period, and S7 (Figure 4), influenced heavily by row crops, can also be compared with typical fertilization dates for vegetables (indicated by downward-pointing arrows) and/or with typical periods of plastic mulch removal (indicated by upward-pointing arrows) for each vegetable season's crop. Normally, vegetables are fertilized when plastic mulch is installed in January for the spring season and August for the fall season. Plastic removal (June and December for the spring and fall seasons, respectively) can be important because rainfall has been shown to leach residual $\mathrm{NO}_{3}-\mathrm{N}$ soon after the plastic is removed from vegetable beds (McNeal, et al. 1995). In contrast, at the beginning of the growing season the likelihood of off-site $\mathrm{NO}_{3}-\mathrm{N}$ movement is normally reduced due to the use of plastic mulch and subirrigation. Irrigation water normally moves upward into the beds during this period, keeping the fertilizer within the root zone. Data from S7 did not show a correlation with either fertilizer-application or plastic-removal dates. There also was no discernable pattern with respect to above-average monthly rainfall (Table 2). In addition, compared with the above-mentioned predominantly citrus stations (S4 and S5), variability tended to be much lower, and concentrations were similar to those for S2, which 


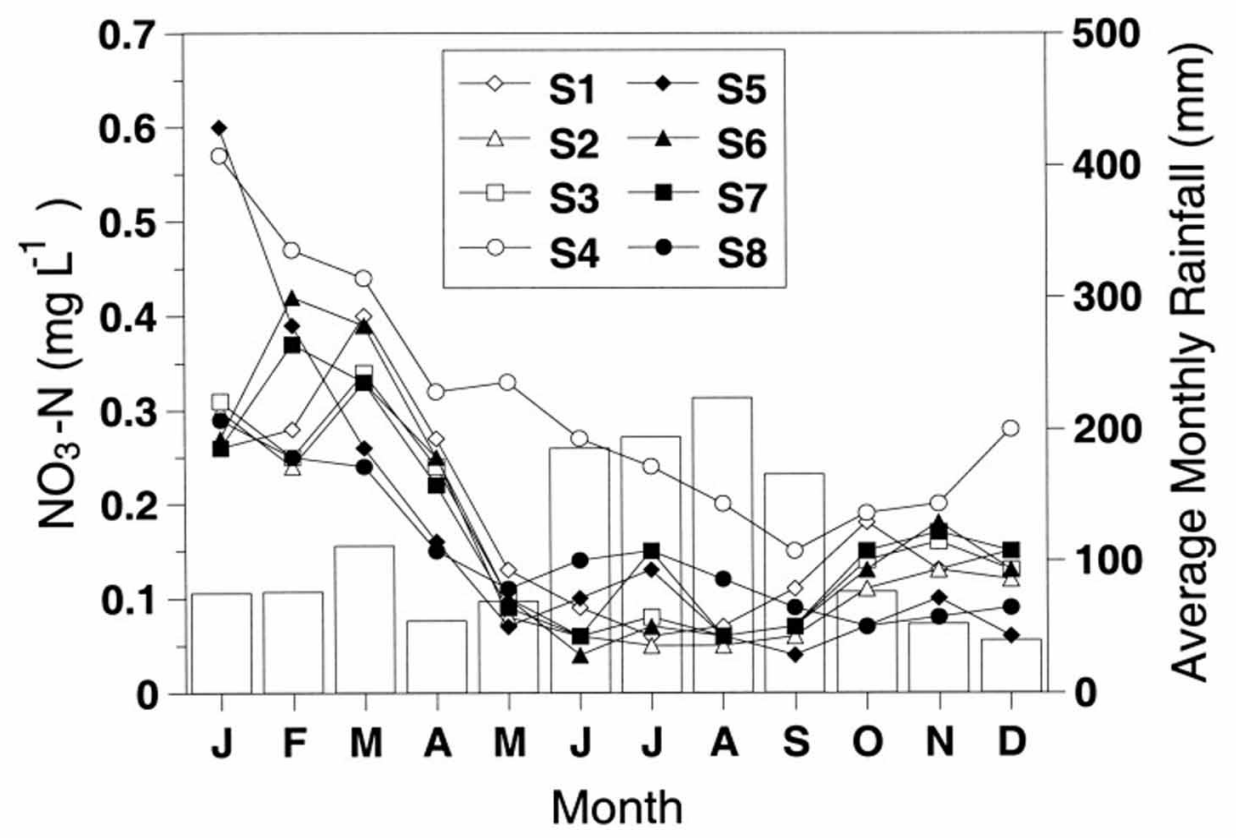

Figure 2. Average monthly $\mathrm{NO}_{3}-\mathrm{N}$ concentrations in water samples taken from eight sampling sites in Lake Manatee, and average monthly rainfall from 1983 to 1992.

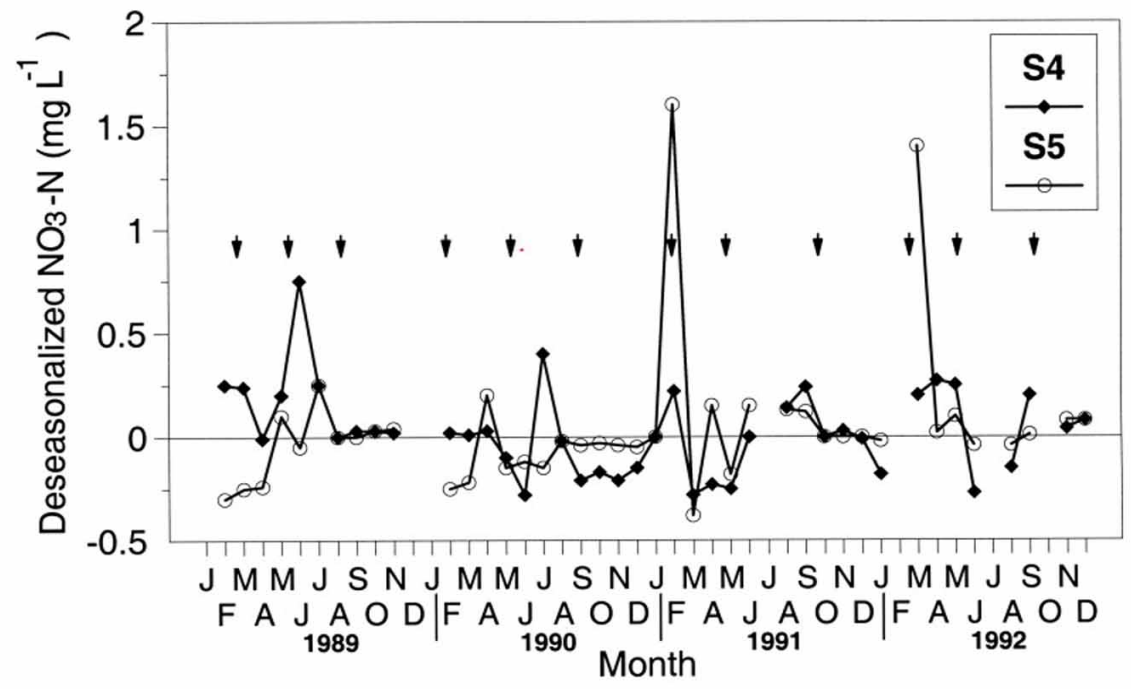

Figure 3. Deseasonalized $\mathrm{NO}_{3}-\mathrm{N}$ trends (from January 1989 to January 1993) compared with typical citrus fertilization dates (indicated by arrows) for S4 and S5 with neighboring citrus production.

had no vegetable or citrus activities. Data from remaining stations, which do not have agricultural activities located nearby, were compared and showed relatively little variation, much like the non-agricultural S2. It appears that it may not be just a question of how much, but also of how close the agricultural activity is to the reservoir that is most important with respect to $\mathrm{NO}_{3}-\mathrm{N}$ inputs. Studies of off-site movement of $\mathrm{NO}_{3}-\mathrm{N}$ from both citrus and vegetable croplands in the Lake Manatee watershed (McNeal et al 1995) have suggested that denitrification may be an important natural 
remediation process in this case. Groundwater $\mathrm{NO}_{3}-\mathrm{N}$ levels beneath vegetable fields were predominantly below $1 \mathrm{mg} \mathrm{L}^{-1}(1 \mathrm{ppm})$ and quickly dissipated whenever spikes of input (as high as 20 $100 \mathrm{mg} \mathrm{L}^{-1}$ (20-100 ppm)) occurred. Subirrigated vegetable fields, which necessarily have high water tables, provide near-optimal conditions for microbes responsible for denitrification. On the other hand, deeply rooted citrus groves often have $\mathrm{NO}_{3}-\mathrm{N}$ concentrations persistently above $10-20 \mathrm{mg} \mathrm{L}^{-1}$ (10-20 ppm). The deep sandy soils, low levels of soluble carbon, and low microbe numbers near the water table at such sites do not appear to provide conditions favoring appreciable denitrification. These low rates of denitrification in sandy soils, in addition to dilution effects, could explain annual trends that are occurring in the Lake Manatee reservoir. over time at the 5\% significance value, although all stations except $\mathrm{S} 4$ showed significant time trends at the $10 \%$ significance value.

Spearman's correlation, which is a non-parametric rank-based correlation, was also administered to determine if there were significant increases or decreases in $\mathrm{NO}_{3}-\mathrm{N}$ concentrations over the study period (Table 3 ). As mentioned earlier, this correlation is not as strongly influenced by extreme values, as are more traditional linear regressions. Although this procedure does not give the actual rate of change, it can be useful when coupled with least-squares linear regression analysis. Data from $\mathrm{S} 1, \mathrm{~S} 3$, and $\mathrm{S} 7$ showed significant $(\mathrm{p}=0.05)$ increasing time trends, and all stations except $\mathrm{S} 4$ and S8 showed significant increases at the $10 \%$ level of significance (Table 3). Depending on the station, $\mathrm{NO}_{3}$-N concentrations increased by $5-10 \%$ each

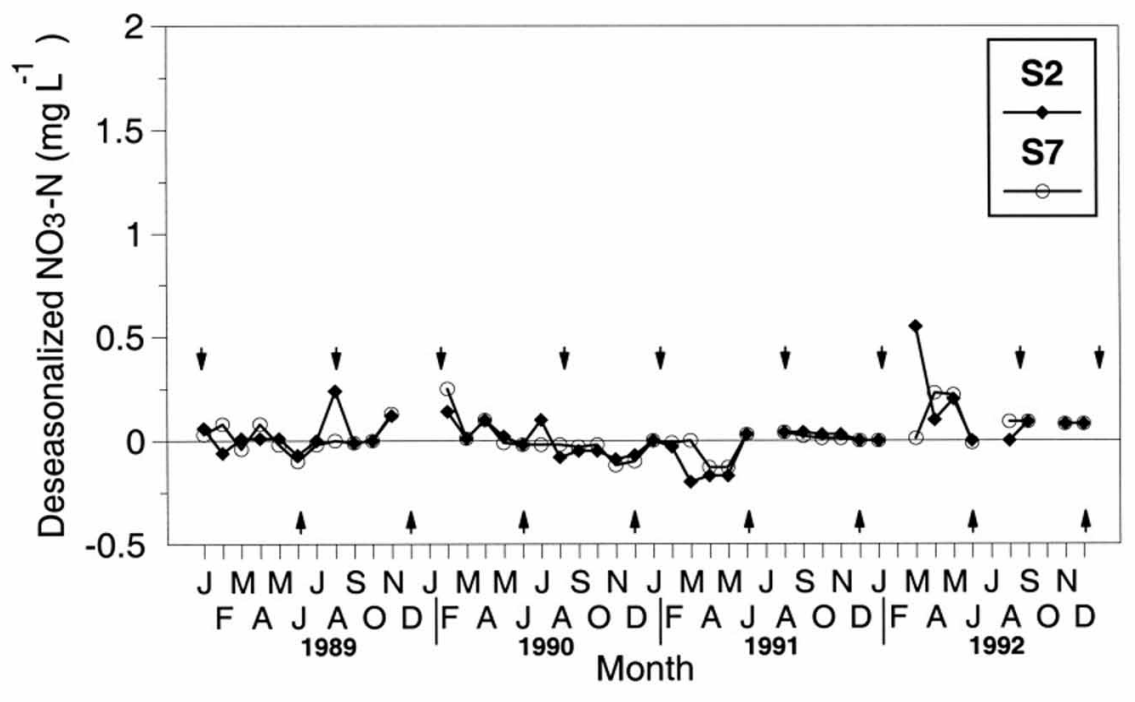

Figure 4. Deseasonalized $\mathrm{NO}_{3}-\mathrm{N}$ trends (from January 1989 to January 1993) compared with typical vegetable fertilization (indicated by downward-pointing arrows) and plastic removal dates (indicated by upward-pointing arrows) for S7 (neighboring vegetable production) and S2 (no agricultural activity).

Trend analysis. Another aspect of this study involved assessing how $\mathrm{NO}_{3}-\mathrm{N}$ concentrations in the reservoir have changed over the 10-year period for each station. Least-squares linear regression analysis was used to calculate the rate of increase (change per year) and accompanying $95 \%$ confidence intervals for these data. Regression analysis was used to determine whether the rate of increase was significantly different from zero (Table 3). Data from S4, S5, and S8 did not show significant trends year, although the average reservoir $\mathrm{NO}_{3}-\mathrm{N}$ concentration was only $0.18 \mathrm{mg} \mathrm{L}^{-1}(0.18 \mathrm{ppm})$ over the entire study period.

Trend analysis was also used to examine normalized $\mathrm{NO}_{3}-\mathrm{N}$ concentration data. Linear regression showed significant trends for S6 and S8 at the $10 \%$ probability level, but not at the $5 \%$ level. Correlation analysis for S2, S6, and S8 also showed significant $(\mathrm{p}=0.10)$ time trends, but they were not significant at $\mathrm{p}=0.05$ (Table 3 ). 
Overall, there was no clear correlation evident between $\mathrm{NO}_{3}-\mathrm{N}$ concentrations in the reservoir and fertilizer application dates. However, data from water sampling stations with neighboring citrus fields did appear to have higher and more widely fluctuating $\mathrm{NO}_{3}-\mathrm{N}$ concentrations than data from stations reflecting primarily row crop areas. Data from all stations except $\mathrm{S} 4$ showed an increasing trend in $\mathrm{NO}_{3}-\mathrm{N}$ levels at the $10 \%$ level of significance for the 10 year sampling period. Station 4 had the highest annual mean $\mathrm{NO}_{3}-\mathrm{N}$ concentrations and remained elevated in $\mathrm{NO}_{3}-\mathrm{N}$ throughout the study period. Depending on the station, the $\mathrm{NO}_{3}-\mathrm{N}$ concentration increased $5-10 \%$ over the 10-year study period. This was also true for $\mathrm{S} 2$, which reflected no citrus or vegetable activities.

The $\mathrm{NO}_{3}-\mathrm{N}$ concentrations also appeared to follow a seasonal pattern, with lower levels during the summer months (June to September). This could be attributed to increased algal, plant, and aquatic weed growth, along with dilution from increased summer rainfall. In regard to nutrient enrichment and subsequent algal growth, it does not appear that it is the amount of agricultural activity in the watershed that is of greatest importance, but rather how close that activity is located to the reservoir. Some citrus production is situated directly adjacent to Lake Manatee, which results in direct surface runoff. The use of riparian buffer zones to control $\mathrm{NO}_{3}-\mathrm{N}$ losses from agricultural lands has been reported throughout the United States (Jacobs and Gilliam 1985; Haycock and Pinay 1993; Jordan et al. 1993) and may be helpful in this situation also. Studies have shown that buffer strips of less than $16 \mathrm{~m}(50 \mathrm{ft})$ can be effective for reducing $\mathrm{NO}_{3}-\mathrm{N}$ levels in drainage waters (Jacobs and Gilliam 1985). Substantial losses in $\mathrm{NO}_{3}-\mathrm{N}$ can occur through denitrification and assimilation by vegetation. If $\mathrm{NO}_{3}-\mathrm{N}$ poses a threat to future water quality in the Lake Manatee reservoir, a buffer zone could be added as a precaution in preserving the quality of the reservoir.

\section{References}

Gee and Jenson, Inc. 1984. Lake Manatee Watershed water resource evaluation - Phase I. Gee and Jenson, Inc., Palm Beach, FL.
Haycock, N.E. and G. Pinay. 1993. Groundwater Nitrate Dynamics in Grass and Poplar Vegetated Riparian Buffer Strips during the Winter. Journal of Environmental Quality 22:273-278.

Jacobs, T.C. and J.W. Gilliam. 1985. Riparian Losses of Nitrate from Agricultural Drainage Waters. Journal of Environmental Quality 14:472-478.

Jordan, T.E., D.L. Correll, and D.E. Weller. 1993. Nutrient Interception by a Riparian Forest Receiving Inputs from Adjacent Cropland. Journal of Environmental Quality 22: 467-473.

McNeal, B.L., C.D. Stanley, W.D. Graham, P.R. Gilreath, D. Downey, and J.F. Creighton. 1995. Nutrient-Loss Trends for Vegetable and Citrus Fields in West-Central Florida: I. Nitrate. Journal of Environmental Quality 24: 95-100.

Rampenthal, S.W. and B.A. Ferraro. 1987. Water quality in central Florida's phosphate mineralized region: Final Report. Pub. No. 03-046-052. Florida Institute of Phosphate Research, Bartow, FL. 
Table 1. Citrus and row crop production areas in sub-basis $\left(1983,1987\right.$, and 1990) presumed to affect $\mathrm{NO}_{3}-\mathrm{N}$ concentrations at specific lake sampling stations.

\begin{tabular}{|l|ccc|ccc|}
\hline & \multicolumn{3}{|c|}{ Citrus (hectares) } & \multicolumn{3}{c|}{ Vegetables (hectares) } \\
& 1983 & 1987 & 1990 & 1983 & 1987 & 1990 \\
\hline Station 1 & 2200 & 2250 & 2200 & 1450 & 1650 & 1450 \\
Station 2 & 0 & 0 & 0 & 0 & 0 & 0 \\
Station 3 & 2125 & 2250 & 2125 & 1300 & 1500 & 1425 \\
Station 4 & 425 & 520 & 415 & 250 & 150 & 110 \\
Station 5 & 1570 & 1510 & 1375 & 1000 & 1320 & 1220 \\
Station 6 & 0 & 0 & 0 & 0 & 0 & 0 \\
Station 7 & 0 & 0 & 0 & 0 & 0 & 0 \\
Station 8 & 1200 & 1200 & 1275 & 480 & 710 & 830 \\
\hline Totals & 7520 & 7766 & 7426 & 6924 & 5488 & 5113 \\
\hline \hline
\end{tabular}

Table 2. Monthly rainfall for Lake Manatee watershed (1989-1992).

\begin{tabular}{|l|cccc|}
\hline \hline \multirow{2}{*}{ Month } & \multicolumn{4}{|c|}{ Monthly Rainfall (cm) } \\
\hline January & 1989 & 1990 & 1991 & 1992 \\
February & 5.8 & 0.4 & 11.5 & 2.2 \\
March & 0.1 & 12.2 & 2.4 & 20.0 \\
April & 5.9 & 2.0 & 9.6 & 9.0 \\
May & 2.9 & 2.2 & 14.2 & 6.2 \\
June & 2.2 & 5.8 & 26.2 & 0.8 \\
July & 30.5 & 27.6 & 22.9 & 44.3 \\
August & 14.0 & 14.7 & 20.3 & 30.0 \\
September & 21.9 & 12.6 & 21.1 & 21.3 \\
October & 35.0 & 10.8 & 12.0 & 14.6 \\
November & 5.8 & 14.8 & 6.6 & 7.1 \\
December & 1.4 & 4.2 & 1.7 & 3.8 \\
\hline \hline
\end{tabular}


Table 3. Least-Squares Linear Regression and Spearman's Correlation Summary Table, Nitrate-N and Deseasonalized Nitrate-N Values Correlated with Sampling Date.

\begin{tabular}{|c|c|c|c|c|c|}
\hline \multirow[b]{2}{*}{ Stn } & & s Linear & ate-N & Spearman & \multirow[b]{2}{*}{ p-value } \\
\hline & p-value & $r^{2}$ & slope & Coefficient & \\
\hline 1 & 0.006 & 0.093 & 0.01447 & 0.26457 & 0.0185 \\
\hline & 0.040 & 0.053 & 0.01075 & 0.20711 & 0.0653 \\
\hline & 0.002 & 0.112 & 0.01635 & 0.31324 & 0.0047 \\
\hline 4 & 0.100 & 0.034 & 0.01443 & 0.14508 & 0.1991 \\
\hline 5 & 0.061 & 0.044 & 0.02309 & 0.18733 & 0.0940 \\
\hline & 0.017 & 0.072 & 0.01712 & 0.20379 & 0.0735 \\
\hline 7 & 0.003 & 0.109 & 0.01831 & 0.31135 & 0.0055 \\
\hline 8 & 0.054 & 0.048 & 0.01037 & 0.18026 & 0.1143 \\
\hline & & s Linear & ized Nitra & & \\
\hline Stn & p-value & $r^{2}$ & slope & Coefficient & $\mathrm{p}$-value \\
\hline 1 & 0.0165 & 0.072 & 0.00927 & 0.24131 & 0.0322 \\
\hline 2 & 0.0502 & 0.048 & 0.00744 & 0.20094 & 0.0739 \\
\hline 3 & 0.0037 & 0.103 & 0.01095 & 0.30112 & 0.0066 \\
\hline 4 & 0.1991 & 0.021 & 0.00936 & 0.17784 & 0.1145 \\
\hline 5 & 0.0424 & 0.051 & 0.02142 & 0.24894 & 0.0250 \\
\hline 6 & 0.0724 & 0.042 & 0.00971 & 0.18806 & 0.0992 \\
\hline 7 & 0.0117 & 0.081 & 0.01202 & 0.26793 & 0.0177 \\
\hline 8 & 0.0616 & 0.045 & 0.00820 & 0.20661 & 0.0695 \\
\hline
\end{tabular}

